\title{
WINTER FEED VALUE OF 'GRASSLANDS MOATA TETRAPLOID ITALIAN RYEGRASS IN SOUTHLAND
}

M.J. Hickey and G.S. Baxter Grasslands Division, DSIR, Gore

\begin{abstract}
Three separate experiments evaluating 'Grasslands Moata' (Lolium multiflorum Lam.) during autumn and winter in Southland are discussed. In two, establishment, productivity and persistence of Moata was compared with 'Grasslands Nui' perennial ryegrass (Lolium perenne L.). 'Grasslands Manawa' short rotation ryegrass (L. perenne $\chi L$ multiflorum) and 'Grasslands Paroa' (L. multifiorum Lam.) and 'Concord' Italian ryegrasses. The third experiment compared ram lamb performance on Moata and Nui.

Moata and Concord established rapidly, both producing $30 \%$ greater autumn/winter growth in the first year than Paroa and Manawa However in the second autumn/winter Moata outyielded the other cultivars by $14 \%$. Moata also outyielded Nui perennial ryegrass during autumn/winter by an average of $10 \%$ over two years.

Lambs grazing Moata during winter had higher liveweight gains than those on Nui (223 ct. $139 \mathrm{~g} / \mathrm{head} /$ day), a result of higher teed intakes of Moata compared with Nui $(2.01 \mathrm{ct} .1 .65 \mathrm{~kg}$ head/day). The differences in teed intake were related to the in vitro digestibility of the two ryegrasses (79\% for Moata ct. $69 \%$ for Nui) and the crude protein levels of the herbage $(22.6 \%$ for Moata ct. $19.3 \%$ for Nui).
\end{abstract}

Keywords: Italian ryegrass. pasture quality, cool-season growth, animal performance, Acremonium endophyte

\section{INTRODUCTION}

Recent development of markets for meat from lean heavy lambs introduces more flexibility into the sheep farming industry in Otago/Southland. Advantages to the meat industry are a more versatile product for additional processing and an extended slaughter period from the traditional November to June. The challenge to the farmer is to grow lambs to suitable weights for winter and spring slaughter. There is a variety of options, but the skills of 'all grass wintering' allow farmers two immediate options. One is the use of autumn-saved pasture and the other is to use a specialist Italian ryegrass. 'Grasslands Moata' tetraploid Italian ryegrass (Lolium multiflorum L.) was bred for better cool-season growth than other Italian ryegrasses (Armstrong 1981).

'Grasslands Tama' tetraploid Westerwolds ryegrass ( $L$ multiflorum Lam.) had higher feed value for dairy cattle during winter than diploids such as 'Grasslands Paroa' Italian ryegrass ( $L$ multiflorum Lam) (Wilson \& Dolby 1976). They also found the Italian ryegrass to be of higher feed value than the perennial ryegrass 'Grasslands Ruanui' (L. perenne L.). Another study, by Brookes 8 Lancashire (1979), showed the feed value of Moata to be as good as that of Tama. Evaluations were initiated to examine the productivity, persistence and feed value for lambs of Moata, in comparison with perennial and other Italian ryegrasses in southern regions of New Zealand.

\section{EXPERIMENT 1}

\section{Cool-season productivity of perennial and Italian ryegrass}

One experiment compared Moata with 'Grasslands Nui' perennial ryegrass $(L$ perenne L.). Moata was direct drilled at $25 \mathrm{~kg} / \mathrm{ha}$ on 14 February 1977 into an 
existing pasture sward following the blanket application of paraquat $(1.5 \mathrm{l} / \mathrm{ha})$ leaving a residual sward of white clover. A 3 year old Nui/Huia pasture was left unsprayed as the control. All plots had common grazing at 6-weekly intervals throughout the year.

In the first autumn after sowing Moata produced significantly less than Nui, because the Moata swards were establishing whereas Nui was an already established sward. Winter production of Moata was significantly greater than that of Nui in the first year (Table 1).

Table 1: Autumn and winter ryegrass yields and total herbage (kg DM/ha) during autumn/winter under grazing

\begin{tabular}{lcccccc}
\hline Cultivar & $\begin{array}{c}\text { Autumn } \\
\text { Feb-Apr }\end{array}$ & $\begin{array}{c}\text { Winter } \\
\text { May-Aug }\end{array}$ & $\begin{array}{c}\text { Total } \\
\text { herbage } \\
\text { Feb-Aug }\end{array}$ & $\begin{array}{c}\text { Autumn } \\
\text { Feb-Apr }\end{array}$ & $\begin{array}{c}1978 \\
\text { Winter } \\
\text { May-Aug }\end{array}$ & $\begin{array}{c}\text { Total } \\
\text { herbage } \\
\text { Feb-Aug }\end{array}$ \\
\hline Nui & 2290 & 1090 & 4880 & 1410 & 1560 & 4070 \\
Moata & 1230 & 2460 & 3840 & 1180 & 2110 & 3850 \\
Isd 5\% & 180 & 270 & 330 & ns & ns & nS \\
\hline
\end{tabular}

The trend of lower autumn production in the second year was related to moisture stress of pasture during summer/autumn. This may have further influenced the growth of Moata by causing prolonged heading, which is notable in Italian ryegrasses in this environment and has also been observed by Stevens 8 Turner (pers.comm.). Once tillers go to seed they die, so tiller density declines and prolonged heading retards autumn recovery of the plant (Hunt \& Field 1978). In the second winter Moata produced almost 30\% more than Nui.

Although total herbage yields accumulated for autumn/winter (Table 1) were greater for Nui pastures in year 1 this difference was compensated largely for by the increased winter activity of Moata. In year 2 total autumn/winter yields were similar, suggesting that Moata could be successfully incorporated into southern farming systemes to enhance animal production during winter.

\section{EXPERIMENT 2}

Productivity and persistence of four Italian tyegrass cultivars

The second experiment compared the herbage production and persistence of Moata with 'Grasslands Manawa', Paroa and 'Concord'. Plots were individually fenced and broadcast sown on 14 March 1985 (Table 2) with 4 kg/ha 'Grasslands Huia' white clover. During establishment all treatments were infrequently grazed until September 1985.

Table 2: Seeding rate, seedling number during establishment and levels of Acremonium endophyte in November 1986

\begin{tabular}{lccc}
\hline & $\begin{array}{c}\text { Seedling } \\
\text { rate } \\
1000 / \mathrm{m}^{2}\end{array}$ & $\begin{array}{c}\text { Seedling } \\
\text { establ. } \\
\text { (21 days) }\end{array}$ & $\begin{array}{c}\% \\
\text { Acremonium } \\
\text { endophyte }\end{array}$ \\
\hline Moata & 36 & 580 & Nil \\
Paroa & 22 & 570 & Nil \\
Concord & 22 & 750 & 62 \\
Manawa & 18 & 580 & 21 \\
Isd 5\% & & 80 & \\
\hline
\end{tabular}

Grazing frequencies of 3- to 4-week and 5- to 6-week intervals were then imposed leaving a $2-3 \mathrm{~cm}$ stubble from spring to autumn. During winter the frequent treatment was grazed twice and the infrequent once. 
Moata and Concord had the best yields in the first winter (Fig. 1). The rapid establishment of Moata is due to tetraploidy, resulting in large seedling tiller size and rapid leaf growth (Armstrong 1981). In contrast, Concord is infected with Acremonium endophyte which may have improved seedling survival (Table 2), as the same number of viable seeds were sown for each cultivar. Seedling vigour studies by Forde et al. (1988) showed good vigour from Concord and suggested Acremonium endophyte may have an effect on this character also.

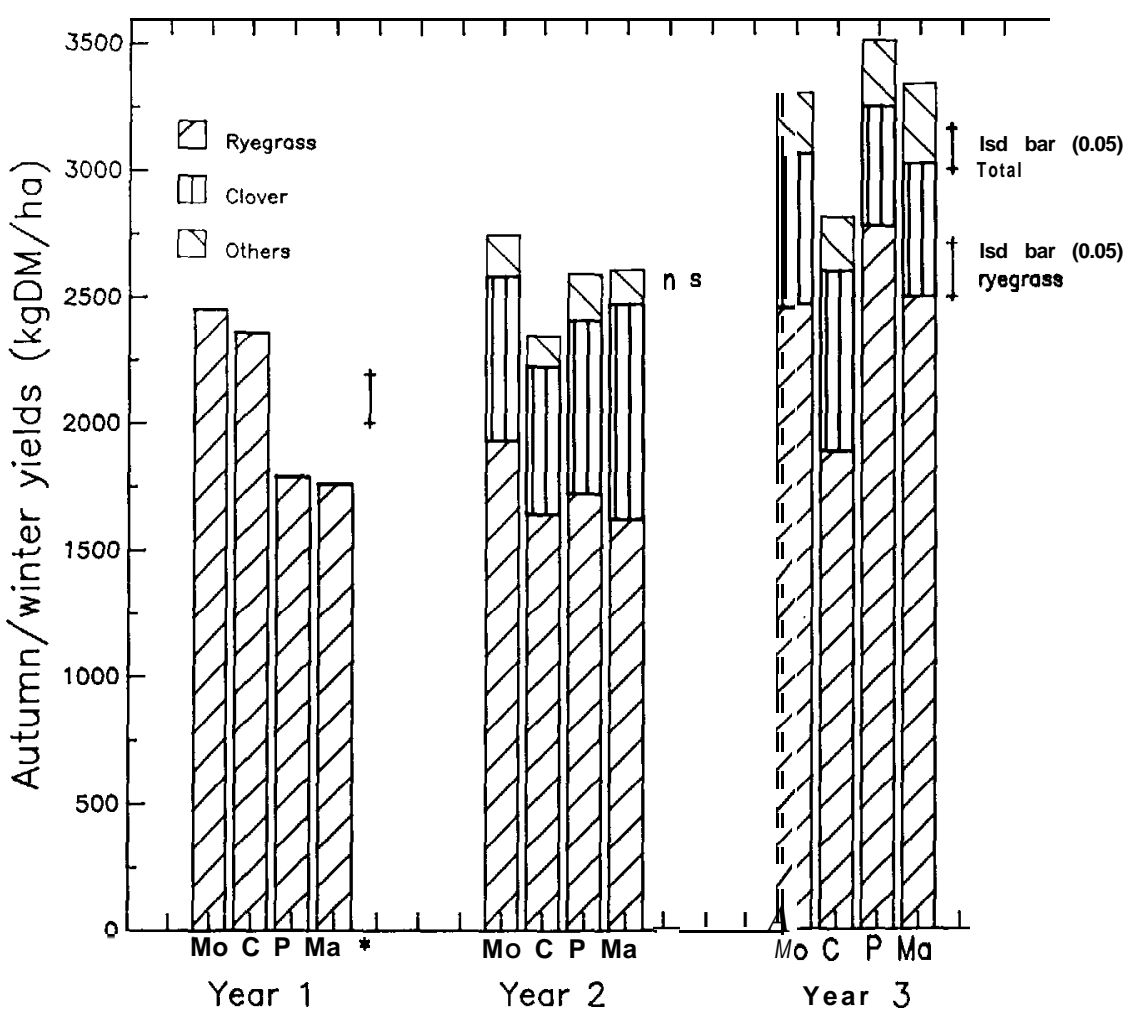

- Mo=Moota C=Concord P=Paroa Ma=Manowo

Figure 1: Autumn/winter yields of four Italian ryegrass pastures

Annual yields of $12800 \mathrm{~kg} \mathrm{DM} / \mathrm{ha}$ on the infrequent grazing management were $12 \%$ greater than under frequent management. This was due to significant differences in spring and summer yields, as the Italian ryegrass component produced less under frequent cf. infrequent grazing (6040 cf. $7520 \mathrm{~kg} \mathrm{DM} / \mathrm{ha}$, $\mathrm{P}<0.05$ ). However, as the grazing management had no affect on autumn and winter yields mean values are presented.

Cultivar performance during the second autumn/winter (Fig. 1) proved that Moata was significantly better than Paroa, Concord and Manawa. By the third autumn/winter Moata still gave adequate ryegrass yields, although its diploid parent Paroa showed greater persistence through higher yields. Manawa equalled Moata but Concord was significantly lower yielding. 
The presence of Acremonium endophyte in harsh environments such as Canterbury may improve the persistence of Concord over other Italian ryegrasses, as occurs for perennial ryegrass (Fletcher 1986). However, endophyte has not had an effect on the persistence of Concord in Otago/Southland.

\section{EXPERIMENT 3}

Winter feed value of Moata and Nui for lambs

Ram lamb growth rates on Moata or Nui ryegrass based pasture were compared over 8 weeks from mid June to mid August 1987. Thirty Coopwotth ram lambs per treatment had an average GR measurement of $5.8 \mathrm{~mm}$ (tissue depth between carcass surface and the 12th rib). Liveweight was measured after overnight fasting. Pasture was break-fed daily and back-fenced to achieve $75 \%$ utilisation. Herbage dry matter yields were measured before and after grazing to calculate animal intakes and to check estimated utilisation. Herbage mass for Moata treatment was in the range of $1500-2100 \mathrm{~kg} \mathrm{DM} / \mathrm{ha}$, and for Nui $\mathbf{2 1 0 0 - 2 5 0 0}$ $\mathrm{kg} \mathrm{DM} / \mathrm{ha}$. The difference in pasture levels was due to a large carry-over of autumnsaved Nui pasture necessary because of its lower winter growth compared with Moata.

Average pasture intakes of Moata were $2.01 \mathrm{~kg} \mathrm{DM} /$ day/lamb and of Nui 1.65 $\mathrm{kg} \mathrm{DM} /$ day/lamb, resulting in average liveweight gains of $226 \mathrm{~g} /$ day for Moata and $139 \mathrm{~g} /$ day for Nui (Fig. 2). The growth rates on Nui are comparable to the gains of 100-150 g/day found in winter 1986 on other perennial pasture (Baxter unpub. data).

Figure 2: Winter lamb weight gains: Nui/Moata 1987.

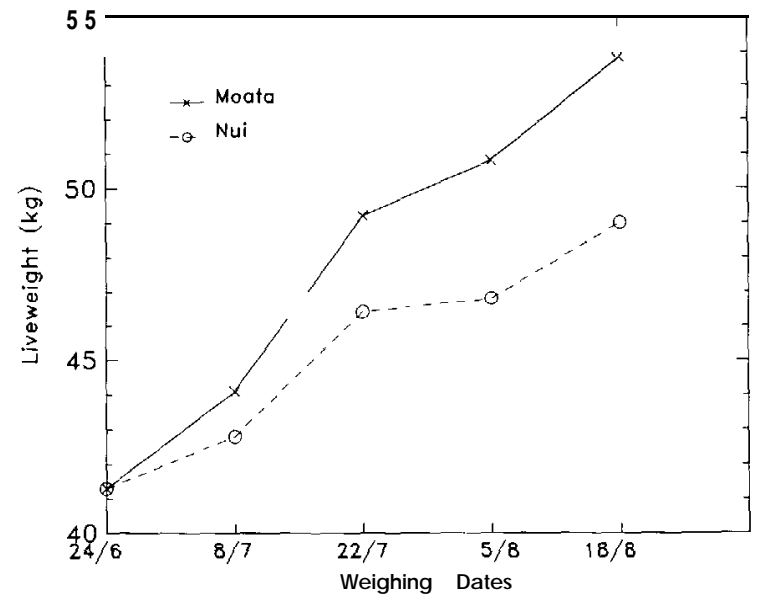

The high level of dead material with Nui, caused by cool winter conditions enhancing the senescence of the autumn-saved Nui pasture, resulted in lower digestibility compared with Moata (Table 3). The active growth and lower herbage mass of Moata ensured this did not occur on these swards. The Moata treatments were higher in both digestibility and protein content (Table 3) than Nui. High soluble carbohydrate levels of Moata (Brookes 8 Lancashire 1980) decreases rumen retention time (Ulyatt et al. 1977) and consequently increases voluntary intakes with Moata.

Independent lamb drafters assessed lambs for GR measurements. At the start of the trial $90 \%$ of the lambs were in the $Y$ grade $(3-7 \mathrm{~mm})$, indicating a high level of 
Table 3: Botanical composition, digestibility and protein content of Moata and Nui pastures

\begin{tabular}{lccccccc}
\hline Cultivar & Ryegrass & $\begin{array}{l}\text { Composition } \\
\text { clover }\end{array}$ & other spp. & Dead & $\begin{array}{c}\text { In vitro } \\
\%\end{array}$ & $\begin{array}{c}\% \\
\text { DOM }\end{array}$ & crude protein \\
\hline Maata & 71 & 9 & 13 & 7 & 79 & 22.6 \\
Nui & 69 & 4 & 6 & 21 & 69 & 19.3 \\
\hline
\end{tabular}

Table 4: GR measurements and distribution of lambs to each grade for lambs fed Moata and Nui

\begin{tabular}{lcccccccc}
\hline & GR(mm) & \%Y & Nui $P$ & \%T \& F & GR(mm) & \%Y Moata & \% P & \%T \& F \\
\hline start & 5.6 & 90 & 10 & 0 & 5.6 & 90 & 10 & 0 \\
6 weeks & 9.5 & 13 & 80 & 7 & 9.0 & 27 & 70 & 3 \\
6 weeks & 9.7 & 70 & 17 & 14 & 14.5 & 13 & 23 & 64 \\
\hline
\end{tabular}

leanness. Six weeks later the average GR had increased to 9.0 and $\mathbf{9 . 5}$ for Moata and Nui respectively (Table 4), but liveweight for Moata had increased to $50.8 \mathrm{~kg}$ whereas Nui liveweights had increased to only $46.8 \mathrm{~kg}$ (Fig. 2).

By the end of the trial at 8 weeks the GR of Moata-fed lambs had increased to $14.5 \mathrm{~mm}$ (Fig. 2) with a corresponding increase in liveweight to $53.8 \mathrm{~kg}$. However because Nui-fed lambs were only $49.1 \mathrm{~kg}$ their GR was only 9.7 , still similar to the GR of Moata lambs at that weight (Table 4). It appears that once these lambs exceeded $50 \mathrm{~kg}$ liveweight then weight gains were mainly by fat deposition. If Moata-fed lambs had been sold at this $50 \mathrm{~kg}$ target weight (Table 4, week 6; Fig. 2) no detrimental effects on grades would have resulted.

Average carcass weights of $23.4 \mathrm{~kg}$ and $19.8 \mathrm{~kg}$ for Moata and Nui respectively achieved dressing out percentages of 43.5 and $41.2 \%$ respectively. Analysis of the dressing out percentage for separate grades showed that within each mob, all grades had the same percentage. Therefore, the degree of fat cover did not influence this character, which means that the decreased rumen retention time of Moata increased the contribution of carcass weight to liveweight. This is important as target liveweights can be reduced, and finishing time can be shortened on Moata swards (Fig. 2).

\section{SUMMARY}

The comparisons between perennial and Italian ryegrasses indicate that Moata can establish rapidly from a late-summer sowing and persist well for at least two winters if grazed at 5- to 6-week intervals and never closer than 2-3 cm.

During autumn/winter Moata outyielded other Italian ryegrasses in the second year by $14 \%$ and Nui perennial ryegrass by an average $10 \%$, thus compensating for initial loss of autumn production.

Superior digestibility and protein levels increased winter intakes of Moata compared with Nui. Perennial ryegrass pastures have to be autumn saved to meet winter requirements, which leads to greater senescence during cool winter conditions compared with actively growing Italian ryegrass pasture.

The higher feed quality/winter intake of Moata produced lamb growth rates which were $60 \%$ greater than those grazing perennial ryegrass swards. Because of these high lamb growth rates in winter, the GR must be monitored closely to ensure that the best grades are obtained.

The active cool-season growth and high feed value of Moata Italian ryegrass emphasises its potential as a specialist grass for the production of winter lambs. Thus farming systems based on perennial ryegrass pastures would benefit from the inclusion of Italian tyegrass. 
Acknowledgements

The authors thank R.J.M. Hay and D.L. Ryan for use of data. Thanks also to K.H. Widdup and D.R. Stevens for advice and comment and KB. Stewart for technical assistance.

\section{References}

Armstrong, C.S. 1981. 'Grasslands Moata' tetraploid Italian ryegrass (Lolium multiflorum Lam.) NZ journal of experimental agriculture 9: 337-4 1.

Brookes, I.M.; Lancashire, J.A. 1979. Production of milk and milk Components by cows grazing different Ryegrass Cultivars. Proceedings NZ Grass/and Association 41: 123-29.

Fletcher, L.R. 1986. Lolium endophyte and sheep performance on perennial ryegrass cultivars. Proceedings NZ Grassland Association 47: 99-105.

Forde, M.B.; Burgess. R.E.; Halligan, E.A.; Gardiner, S.E.; Latch, G.C.M. 1988. Varieties of Italian nyegrass in New Zealand. Proceedings N2 Grassland Association 49: 101-I 06.

Hunt, W.F.; Field, T.R.O. 1978. Growth characteristics of perennial ryegrass. Proceedings NZ Grassland Association 49: 101-106.

Hunt, W.F.; Field, T.R.O. 1976. Growth characteristics of perennial ryegrass, Proceedings NZ Grassland Association 40: 101-i 3.

Ulyatt, M.J.; Lancashire, J.A.; Jones. W.T. 1977. The nutritive value of legumes. Proceedings NZ Grassland Association 38 Pt. 1: 107-I 8.

Wilson, G.F.: Dolby, R.M. 1967: Ryegrass varieties in relation to dairy cattle performance. NZ journal of agricultural research 10: $415-24$ 